\title{
Measuring the Impact of Trade Flows on Employment in the Turkish Manufacturing Industry
}

\author{
Guzin Erlat \\ Middle East Technical University
}

Follow this and additional works at: https://ecommons.luc.edu/meea

Part of the Economics Commons

\section{Recommended Citation}

Erlat, Guzin, "Measuring the Impact of Trade Flows on Employment in the Turkish Manufacturing Industry". Topics in Middle Eastern and North African Economies, electronic journal, 1, Middle East Economic Association and Loyola University Chicago, 1999, http://www.luc.edu/orgs/meea/

This Article is brought to you for free and open access by the Journals and Magazines at Loyola eCommons. It has been accepted for inclusion in Topics in Middle Eastern and North African Economies by an authorized administrator of Loyola eCommons. For more information, please contact ecommons@luc.edu.

(C) 1999 by the authors 


\title{
MEASURING THE IMPACT OF TRADE FLOWS ON EMPLOYMENT
}

\section{IN THE TURKISH MANUFACTURING INDUSTRY}

Guzin Erlat*, Department of Economics, Middle East Technical University, Ankara, Turkey, E-mail: gerlat@rorqual.metu.edu.tr

\begin{abstract}
This paper investigates the impact of export and import flows on the change in manufacturing employment using an accounting-identity based approach which enables the change in employment to be decomposed into the contribution made not only by trade but also by domestic consumption and productivity change. The analysis is carried over (i) four subperiods, two belonging to the period before 1980 when Turkey switched from a regime of import-substitution based growth to one of export-orientation, and the other two, to the period after 1980, and (ii) three trade-based categories; net exporting, import competing and non-competing sectors. We find (a) that trade has a more significant role to play in employment change in the post-1980 periods, (b) that this is observed more in the net exporting and non-competing categories rather than the import competing category, and (c) that the switch to export-oriented growth in 1980 did not lead to exportbased employment to be dominant in employment changes but has acted as a buffer in the sense that employment may either have grown much less or declined more severely if the post-1980 expansion of exports had not occurred.
\end{abstract}

\section{Introduction}

The question of trade and employment has been approached from two different view points in the literature depending upon whether the focus was on the developed countries trying to assess the potential loss in employment due to the penetration of imports from developing countries or on developing countries trying to exploit the potential for increasing employment by switching to an export-promoting trade regime due to the labour intensive nature of the production of exportables. (See Renshaw, 1981 and Wood, 1994.)

In a previous study (Erlat, 1998a), we took up the second point of view and investigated the effects of trade regime shifts on employment in the Turkish manufacturing industry following the procedure developed by Krueger et al. (1981). This was of particular interest since Turkey had undergone a major shift in its trade regime in 1980 by switching from a policy of import-substitution based growth to a policy of export-led growth. One of the main conclusions of that study was that, having found export industries to be more labour intensive than import-competing industries, the potential for an increase in employment when one switches to an export promoting regime existed, but whether it actually had been the contributing factor to the observed increases in employment appeared debatable, leading one to conjecture that non-trade factors may be more important in explaining the growth of employment.

The purpose of the present paper is to shed some light on this question. In doing so, we shall implement an accounting-identity based tool used primarily to investigate the effects of import penetration on employment in developed countries. (See, e.g., Schatz and Wolter, 1981, Balasubramanyam and Salisu, 1993). This will enable us to separate out the effects of changes in domestic consumption and productivity on changes in employment.

Our analysis was carried out at three levels of aggregation: The manufacturing sector as a whole; the industries grouped as net exporting, import-competing, and non-competing (as was done in Erlat (1998a), where the details may be found, following the procedure in Krueger et al. (1981)); individual industries within the context of their group memberships. We shall only report the findings on the first two levels, referring the reader to Erlat (1998b) for the results on the third level.

The plan of the paper is as follows. In the next Section, we shall describe the data and, in Section 3, we shall 
take a closer look at the employment, import and export series for the manufacturing industry as a whole. Section 4 will contain a description of the identity-based measurement method utilized and the empirical results will be presented in Section 5. Our conclusions will be in Section 6.

\section{The Data}

We have series on employment, output, imports and exports. The employment and output data have been obtained from the UNIDO (1997) database and cover the period 1963-1994. The output data are available in both TL and SUS terms and are in current prices. The import and export data have been obtained from the database of the Undersecretariat of Foreign Trade and cover the period 1969-1996. Thus, our analysis will cover the 1969-1994 period common to both sets of data. All data are provided in terms of the ISIC (revision 2) three-digit classification.

The trade data was in SUS terms and in current prices. It was transformed into TL terms by using the periodaverage annual exchange rates from Erlat and Arslaner (1997, Table 2). All TL. based series were converted to real terms by using the Wholesale Price Index $(1987=100)$, obtained from the State Institute of Statistics database, as the deflator.

\section{An Overall Look at Employment and Trade in The Manufacturing Sector}

When we look at the employment, export and import series for the manufacturing sector as a whole, we note that we may distinguish four subperiods: 1969-1978, 1979-1981, 1982-1990, and 1991-1994. The first and third subperiods correspond to periods of employment growth while the periods 1979-1981 and 1991-1994 are periods of crises for the economy as a whole, the latter culminating in the financial crisis of 1994 . The first employment growth period takes place during the import substitution regime, while the second subperiod is observed during the export promotion regime when a large increase in exports were realized. Since, as established in Erlat (1998a), exports are labour intensive while import competing products are less so, then one, apparently, needs to explain the growth of manufacturing employment during the first period with reference to other factors. The picture in the post-1980 period, however, does appear to suggest that a shift in the trade regime may have had a nonnegligible effect on employment growth in the manufacturing sector as a whole. In fact, Erlat (1998a)'s findings indicate that the employment creation capacity of exports outstrips the employment displacement capacity of imports in the years 1985, 1988, 1989 and 1994. Thus, we decided to perform our calculations for the four subperiods listed above.

\section{The Method}

The approach we wish to take in investigating the effect of changes in trade on changes in employment is to link the latter change to various components through the use of identities. Letting the subscripts ' 0 ' and ' 1 ' refer to the beginning and ending period values, the change in employment between these two periods may be expressed as

(1) $\mathrm{E}_{1}-\mathrm{E}_{0} \equiv\left(\mathrm{C}_{1}-\mathrm{C}_{0}\right) \mathrm{L}_{0}+\mathrm{Q}_{1}\left(\mathrm{~L}_{1}-\mathrm{L}_{0}\right)+\left(\mathrm{M}_{0}-\mathrm{M}_{1}\right) \mathrm{L}_{0}+\left(\mathrm{X}_{1}-\mathrm{X}_{0}\right) \mathrm{L}_{0}$

where $\mathrm{E}$ is employment, $\mathrm{Q}$ is real output measured in domestic currency, $\mathrm{L}$ is the labour requirement coefficient $(=\mathrm{E} / \mathrm{Q})$, measured as the number of employed required to produce 1 billion TL worth of output at 1987 prices, or the reciprocal of average labour productivity, and $\mathrm{C}$ is domestic consumption $(\equiv \mathrm{Q}-\mathrm{X}+\mathrm{M})$. We, thus, decompose the change in employment between these two periods into the contributions made by the change in domestic consumption, the change in labour requirements (or productivity), the change in imports and the change in exports. The contributions of domestic consumption, imports and exports are all measured similarly. Taking domestic consumption as an example, its contribution to the change in employment is measured as the difference between estimated employment associated with $\mathrm{C}$ at period 1 based on labour requirements at $0, \mathrm{C}_{1} \mathrm{~L}_{0}$, and actual employment generated by $\mathrm{C}$ at period $0, \mathrm{C}_{0} \mathrm{~L}_{0}$. The 
contribution of labour requirements, or productivity, on the other hand, may be expressed as $Q_{1}\left(L_{1}-L_{0}\right)=E_{1}-Q_{1} \cdot L_{0}$ and measures the difference between actual employment at period 1 and the estimate of the employment required to produce $Q_{1}$ at period 0 productivity levels. If there has been an increase in productivity, then the estimated employment to produce ${ }^{Q_{1}}$ would be more than the actual employment, contributing negatively to the actual change in employment.

This approach has been criticized by Martin and Evans (1982) because $E_{1}-E_{2}$ could also be decomposed based on period 1 instead of period 0 , leading to different quantitative results. This decomposition, together with its application to our data, are given in Erlat (1998b) where it was shown that the results based on identity (1) were found to be quite robust to the change in the base period.

\section{Empirical Results}

As pointed out in the Introduction, we shall consider the results pertaining to the first two levels of aggregation; , namely, the manufacturing sector as a whole and the three sector categories. They are given in

TABLE 1- AGGREGATE RESULTS

\begin{tabular}{lrrrrrrrrr} 
& & \multicolumn{1}{c}{$\Delta \mathrm{E}^{*}$} & \multicolumn{1}{c}{$\%$} & \multicolumn{1}{c}{$\Delta \mathrm{E}_{C^{*}}$} & \multicolumn{1}{c}{$\%$} & \multicolumn{1}{c}{$\Delta \mathrm{E}_{\mathrm{P}}{ }^{*}$} & \multicolumn{1}{c}{$\%$} & \multicolumn{1}{c}{$\Delta \mathrm{E}_{\mathrm{M}}{ }^{*}$} & \multicolumn{1}{c}{$\%$} \\
\hline The & $1969-1978$ & 399520 & 99.9 & 699137 & 174.7 & -235778 & -58.9 & -80488 & -20.1 \\
Manufacturing & $1979-1981$ & $\mathbf{8 1 0 0}$ & 1.0 & 302700 & 38.3 & -279835 & -35.4 & -68411 & -8.7 \\
& $1982-1990$ & 148012 & 17.9 & 55785 & 79.2 & -426757 & -51.5 & -193266 & -23.3 \\
& $1991-1994$ & -12543 & -1.4 & 18400 & 2.0 & -60391 & -6.7 & -71045 & -7.9 \\
\hline Net Exporters & $1969-1978$ & 159450 & 69.9 & 243369 & 106.8 & -98986 & -43.4 & 138 & 0.1 \\
& $1979-1981$ & 7600 & 2.0 & 66716 & 17.3 & -87822 & -22.7 & -8552 & -2.2 \\
& $1982-1990$ & 100498 & 27.4 & 230263 & 62.7 & -189861 & -51.7 & -39118 & -10.7 \\
& $1991-1994$ & 7399 & 1.7 & 8073 & 1.9 & -55660 & -13.1 & -23346 & -5.5 \\
\hline Import & $1969-1978$ & 189440 & 123.5 & 298054 & 194.3 & -75591 & -49.3 & $-\mathbf{3 5 4 9 5}$ & -23.1 \\
Competing & $1979-1981$ & -6200 & -1.9 & 165049 & 49.5 & -164636 & -49.4 & -23356 & -7.0 \\
Sectors & $1982-1990$ & 46105 & 11.3 & 320086 & 78.7 & -213420 & -52.5 & -91308 & -22.4 \\
& $1991-1994$ & -18038 & -4.2 & 7377 & 1.7 & -21836 & -5.1 & -33072 & -7.8 \\
\hline Non- & $1969-1978$ & 50630 & 269.7 & 141703 & 754.9 & -50005 & -266.4 & -41881 & -223.1 \\
competing & $1979-1981$ & 4300 & 6.1 & 42922 & 61.0 & -14630 & -20.8 & -27413 & -38.9 \\
Sectors & $1982-1990$ & 1409 & 2.6 & 109793 & 201.5 & -42950 & -78.8 & -68135 & -125.0 \\
& $1991-1994$ & -1904 & -3.8 & 3350 & 6.7 & 1348 & 2.7 & -12737 & -25.5
\end{tabular}

$* \quad \Delta E$ stands for the total change in employment while $\Delta \mathbf{E}_{\mathrm{C}}, \Delta \mathbf{E}_{\mathrm{P}}, \Delta \mathbf{E}_{\mathrm{M}}$, and $\Delta \mathrm{E}_{\mathrm{X}}$ stand for the changes in total employment during consumption, productivity change, imports and exports, respectively.

Table 1.

We shall consider the results pertaining to the manufacturing sector first. We note that the highest increase in employment is observed in the 1969-1978 period, this increase diminishes to $1 \%$ in the following subperiods. These two subperiods constitute the pre-1980 period and we note that the dominant factor which leads to increases in employment in both subperiods is the increase in domestic consumption. This increase diminishes considerably during 1979-1981 but it is still strong enough to overcome the employment displacement effects of increases in productivity and imports. The highest displacement effect, in both periods, is due to reduction in direct labour requirements or increases in average productivity rather than increases in imports.

In the post-1980 period, we get a $17.9 \%$ increase in employment in the 1982-1990 subperiod followed by a decrease of $1.4 \%$ in 1991-1994. Even though the first subperiod refers to the period of highest export 
growth, its contribution to employment increase is only $13.6 \%$, compared to the $79.2 \%$ contribution of the increase in domestic consumption. However, it should be noted that without this increase in export-based employment, the increase in overall employment would only be $4.3 \%$ due to the total employment displacement effect of the increase in productivity and imports of $74.8 \%$. Even though the major part of this percentage is due to productivity growth, as was the case in the previous two subperiods, the share of imports has increased instead of diminishing. Thus, it is safe to say that the post-1980 increase in exports observed in 1982-1990 has had a nonnegligible effect on employment growth in the sector as a whole but has not shown its full effect due to the concomitant increase in imports during the same period. Nevertheless, in 1991-1994, during which the economy passed through a serious crisis towards the end of the term, the decrease in employment would have been $12.6 \%$ instead of just $1.4 \%$ but for the continued contribution made by the increase in exports.

When we next turn to the three sector categories, we shall first consider the net exporting category, and we note that, even though the net effect of trade is positive for both subperiods prior to 1980, the overall effect is still dominated by increases in domestic consumption and productivity. The employment increase due to exports are, however, once again instrumental in offsetting the displacement effect of productivity increases during the crisis period of 1979-1981. The largest contribution of exports are observed, as expected, during the 1982-1990 period and we may say that the $27.4 \%$ increase in employment could be attributed to the increase in exports since the trade off between the increase in domestic consumption and the combined displacement effects of productivity and import increases left over a mere $0.4 \%$ increase in employment. Of course, increases due to exports were again instrumental in preventing a decrease in overall employment during the 1991-1994 period.

The picture observed from the import-competing category results are somewhat closer to those observed for the manufacturing sector as a whole, but in sharper relief. For example, there is now a decrease in employment during the 1979-1981 period and may be said to be due to the $2 \%$ negative trade effect. The increase in employment during the 1982-1990 period is lower than that observed for the exporting sector and, to a great extent, is due to the continued presence of a $22.4 \%$ displacement effect caused by imports. In fact, the effect of imports dominate in leading to a decrease of $4.2 \%$ in overall employment in the last subperiod. This figure could have been higher if a certain amount of increase in exports had not been achieved during the post-1980 period.

In the non-competing category, there are only three individual sectors during 1969-1981 and two sectors during 1982-1994. Thus, the absolute employment change figures are smaller in magnitude and they differ considerably depending upon the presence of the sector 351 "Industrial Chemicals". Hence, we note that, even though the percentage increase in employment drops tremendously during 1979-1981, it still is at a level higher than one observes for the exporting sector. On the other hand, with 351 becoming import competing after 1982, we obtain the lowest employment increase for the 1982-1990 period; this, to a great extent, is due to the displacement caused by the increase in imports. In fact, the displacement effect of imports dominates the displacement effect of productivity increases for three out of four subperiods and it, in fact, is the determining factor of the decrease in employment during 1991-1994.

\section{Conclusions}

1. We found, in all cases considered, that the factor which accounted for the considerable increase in employment during the 1969-1978 period was the increase in domestic consumption based employment and the major negative factor was the increase in average productivity.

2. During the crisis period of 1978-1982 we observe a sharp decrease in the growth of domestic consumption based employment and we now observe that trade-based changes in employment became more effective. In the case of the manufacturing sector as a whole and in the net exporting category, it is the increase in exportbased employment which leads to a small, but still, positive, change in employment; this is reversed in the case of the import-competing category and the source of the decrease in employment appears to be the 
displacement effect of imports.

3. During the first post-1980 subperiod, 1982-1990, we observe an increase in employment, both for the manufacturing sector as a whole and for all categories, but not at the level, in both the absolute and percentage senses, of the 1969-1978 period. However, it is interesting to note that it is the net exporting category which comes closest to the absolute increase itself achieved in 1969-1978. The contribution of export-based employment appears to have been decisive during this period. The increase in the importcompeting category is less than half of that in the net exporting category and the main source of this poorer performance is the continued high displacement effect of imports. The increase in employment is even lower in the non-competing category and the dominance of employment displacement due to imports is undisputed.

4. The final period, 1991-1994, is again a crisis period and we find that only the net exporting category come out with an increase instead of a decrease in employment. Export-based employment growth is obviously the basic source of this result, as it is in the other two categories, in leading to decreases in employment which might have been much worse without its increasing contribution.

5. In sum, our results appear to indicate that if one of the major reasons for switching to an export -oriented growth regime was to increase employment, then the Turkish experience, within the context of the manufacturing industry, indicates that such high expectations were not justified. Nevertheless, the evidence does indicate that such a change in policy has been beneficial to employment, acting, in particular as a buffer in periods of crises when the effects of domestic factors are greatly diminished.

* I would like to express my sincere thanks to Professor Tuncer Bulutay who initiated my research on this topic for an ILO paper (Erlat, 1998a), to Professor Erol Taymaz who generously shared the UNIDO Database with me and last but, of course, not least, to Professor Haluk Erlat who read the paper first, as always, and made valuable suggestions and criticisms.

\section{References}

Balasubramanyam, V.N. and Salisu, M.A., "International Trade and Employment in the UK Textiles and Clothing Sector," Applied Economics, 1993, 25, 1477-1482.

Erlat, G., (1998a) "Foreign Trade and Employment in Turkey", in Labour Statistics, 1997, Ankara: State Institute of Statistics, 1998, 139-159.

Erlat, G., (1998b) "Measuring the Impact of Trade Flows on Employment in the Turkish Manufacturing Industry", ERC Working Paper No. 98/3, METU Economic Research Center, 1998.

Erlat, G. and Arslaner, F., "Measuring the Real Exchange Rate: Annual Series for Turkey, ERC Working Paper No. 97/10, METU Economic Research Center, 1997.

Krueger, A.O., Lary, H.B., Manson, T. and Akrasanee, N. eds., Trade and Employment in Developing Countries 1 : Individual Studies, Chicago: University of Chicago Press, 1981.

Martin, J. P., and Evans, J. M., Notes on Measuring the Employment Displacement Effects of Trade by The Accounting Procedure", Oxford Economic Papers, 1981, 33, 154-164.

Renshaw, G. ed., Employment, Trade and North-South Cooperation, Geneva: International Labour Office, 1981.

Schatz, K. W. and Wolter, F., "The Federal Republic of Germany" in G. Renshaw ed., Employment, Trade and North-South Cooperation, Geneva: International Labour Office, 1981, 181-207.

UNIDO, UNIDO Industrial Statistics Database, 1997, Vienna: United Nations Industrial Development 
Organization, 1997.

Wood, A., North-South Trade, Employment and Inequality, Oxford: Oxford University Press, 1994. 